UDC 579.69

\title{
DETERMINATION OF ANTAGONISTIC ACTIVITY OF EXTRACTS OF MEDICINAL PLANTS ON ORAL BACTERIA
}

\author{
Y. V. BORYSENKO, M. M. BARANOVSKYI \\ National Aviation University, Kyiv
}

Last decade's apparent problem is concerned with the use of synthetic medicines. Natural products provide unlimited opportunities for new drug discoveries. Human host and its microbial flora constitute a complex ecosystem. Any shifts in such equilibrium could cause the development of infectious diseases. It is important to determine the features of antagonistic properties of herbs' extracts in order to develop drugs for the treatment and prevention of infectious diseases as the one of the most urgent task of modern biotechnology.

Key words: oral cavity, medicinal plant, extraction, antagonistic activity, agar well diffusion, inhibition.

Introduction. Pathogenic microorganisms cause infectious diseases the treatment of which by synthetic medicines leads to the development of pathogenic microflora resistance, dysbiosis, frequent side-effects and the emergence of allergic reactions. Natural products, such as plants extract, either as pure compounds or as standardized extracts, provide unlimited opportunities for new drug discoveries because of the unmatched availability of chemical diversity. Plants used for traditional medicine contain a wide range of substances that can be used to treat chronic as well as infectious diseases. Herbs typically cause fewer side-effects comparing with synthetic medicines, but in principle, herbal medicines have the potential to elicit the same types of adverse reactions as synthetic drugs. Extraction is the crucial first step in the analysis of medicinal plants, because it is necessary to extract the desired chemical components from the plant materials for further separation and characterization. 
Human host and its microbial flora constitute a complex ecosystem whose equilibrium serves as a remarkable example of reciprocal adaptation. Numerous studies have demonstrated the intimate relationship between infection and dysbiosis of the microbiota, and have shown that infection is associated both with pathogens that penetrate the organism and the resident microbial flora of mucosal ways. In recent decades, a tremendous amount of evidence has strongly suggested a crucial role of the human microbiota in human health and disease via several mechanisms. First, the microbiota has the potential to increase energy extraction from food, increase nutrient harvest, and alter appetite signaling. The microbiota contains far more versatile metabolic genes than are found in the human genome, and provides humans with unique and specific enzymes and biochemical pathways. Second, the human microbiota also provides a physical barrier, protecting its host against foreign pathogens through competitive exclusion and the production of antimicrobial substances. Finally, the microbiota is essential in the development of the mucosa and immune system of the host.

The association between oral diseases and the oral microbiota is well established. Of the more than 750 species of bacteria that inhabit the oral cavity, a number are implicated in oral diseases. The development of dental caries involves acidogenic and aciduric Gram-positive bacteria. Periodontal diseases have been linked to anaerobic Gram-negative bacteria.

Materials and methods of research. There are five stages of the research: (a) cultivation of microorganisms on MRS, Blood agar, Endo agar, Hiss-medium (with lactose), (b) isolation of pure culture bacteria, (c) identification of bacteria, (d) preparation of medicinal plant extracts, (e) analysis of antagonistic activity of medicinal plant extracts on bacteria.

Cultivation of microorganisms on MRS, Blood agar, Endo agar, Hiss-medium (with lactose). For the cultivation of microorganisms under laboratory conditions, culture media are an essential prerequisite. In order to achieve good growth, appropriate media must be used. There are four categories of media used in laboratory: (a) enrichment media (Blood agar); (b) selective media; (c) differential media (Endo 
agar, Hiss-medium); (d) propagation media (MRS). Cultivation of aerobic bacteria is usually performed in covered glass or plastic Petri dishes. Blood agar is enriched medium used to culture a wide range of pathogens particularly those that are more difficult to grow on MRS (Streptococcus spp., Neisseria spp.). It is also a differential media in allowing the detection of hemolysis (destroying the RBC) by cytolytic toxins secreted by some bacteria, such as certain strains of Bacillus, Streptococcus, Enterococcus, Staphylococcus, and Aerococcus. Endo agar is a selective medium recommended for confirmation of the presumptive test for members of the lactose fermenting coliforms. Lactose fermenting coliforms produce aldehyde and acid. The aldehyde in turn liberates fuchsin from the fuchsin-sulphite complex, giving rise to a red colouration of colonies. Hiss-medium is used for identification of Enterobacteriaceae fermentation of the dough from carbohydrates (lactose, glucose, sucrose, maltose) or a polyhydric alcohol (mannitol). The medium indicator, bromocresol purple, when fermenting carbohydrate and releasing acid, changes the color from violet to yellow.

The samples of $\mathrm{m} / \mathrm{o}$ from the front and back teeth, cheeks and tongue with the use of sterilized swabs were taken, put on Petri plates and incubated at $36-37^{\circ} \mathrm{C}$ for 48 hours. As a result the growth of bacteria of different species from the tongue and toothbrush on the differential media as Endo agar and Hiss-medium was observed (indicates the cultivation of Enterobacteriaceae) (Fig. 1). The growth of bacteria of different species from the oral cavity with $\alpha$-hemolysis on Blood agar was observed (indicates the cultivation of bacteria of Streptococcus spp. or Staphylococcus spp.) (Fig. 2). 


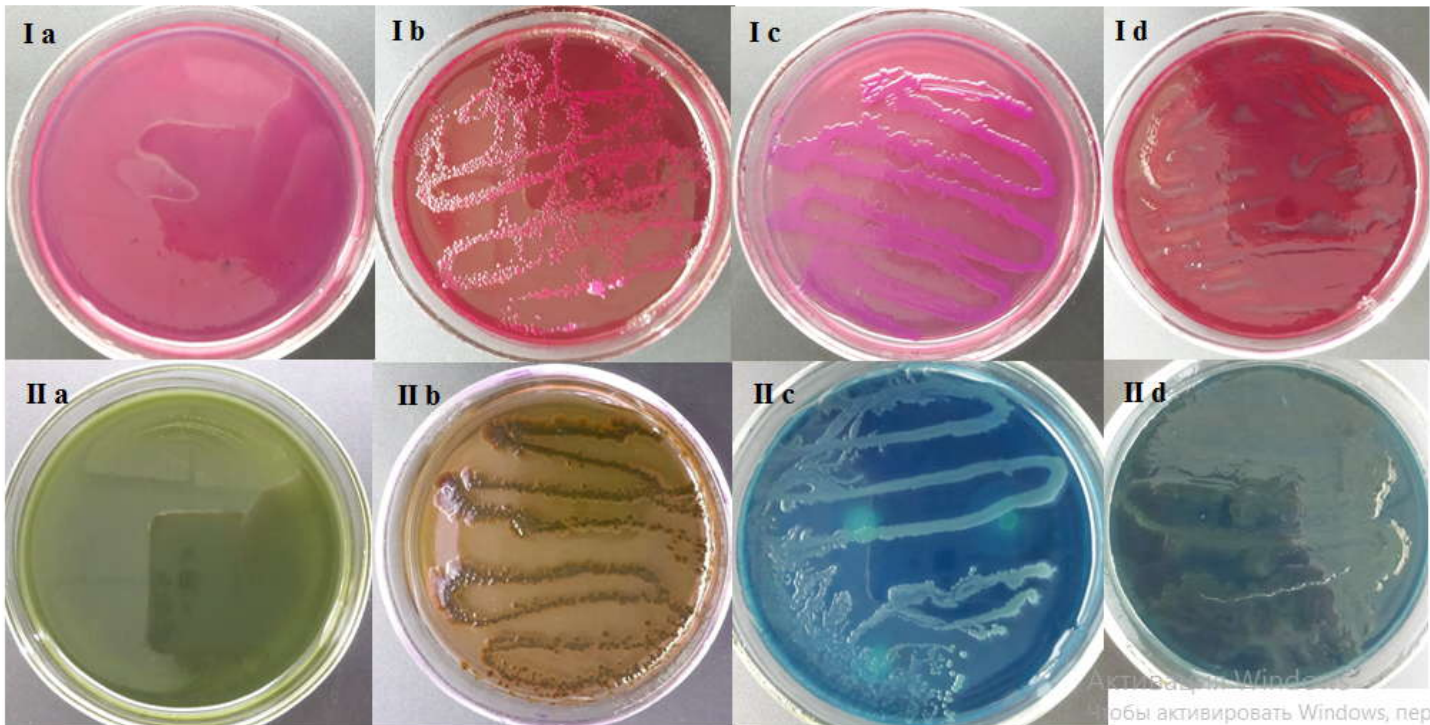

Fig. 1 Microorganisms that grew up on Endo agar and Hiss-medium:

I a - pure sample of Endo agar, II b-pure sample of Hiss-medium;

Escherichia coli (taken from the department of biotechnology's collection) on

(b); the sample from the tongue (c); the sample from the toothbrush (d)

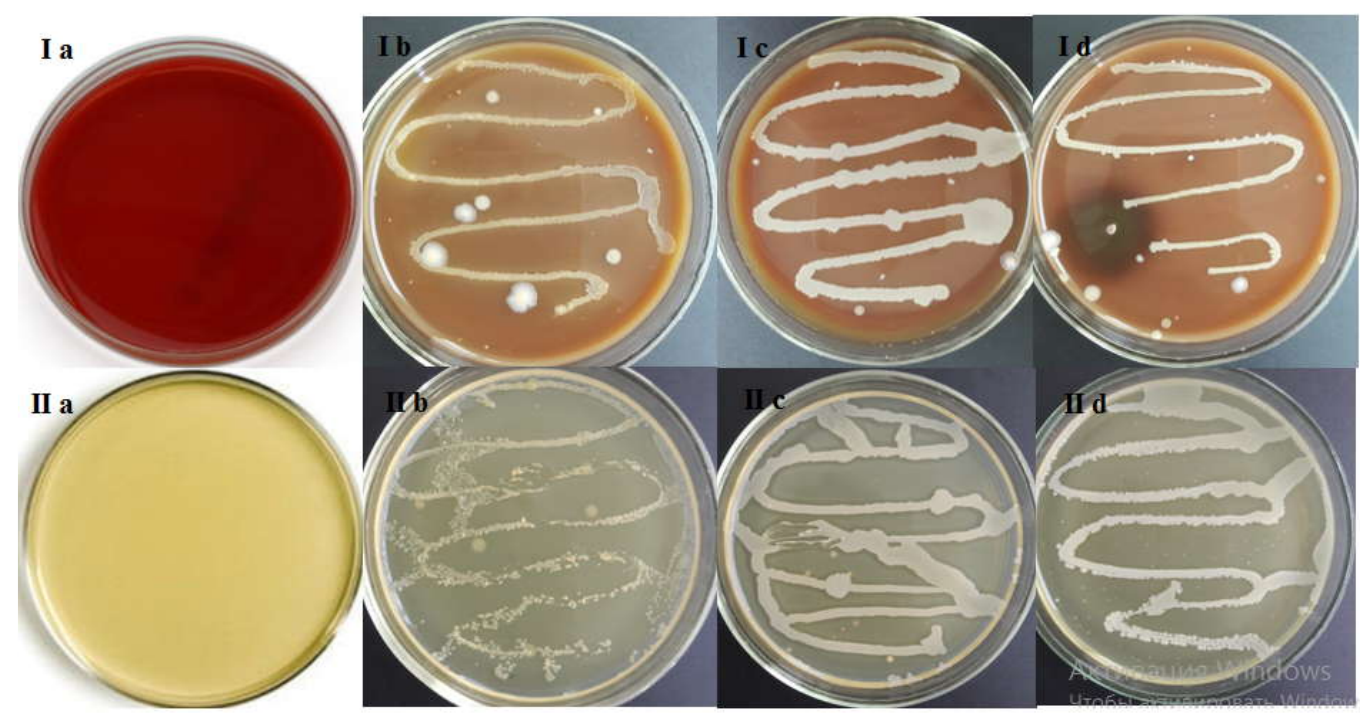

Fig. 2 Microorganisms that grew up on Blood agar and MRS: I a - pure sample of Blood agar,

II b - pure sample of Hiss medium; the sample from the tooth (b); the sample from the nasal cavity (c); the sample from the nasal cavity (d) 
Isolation of pure culture bacteria. The three most commonly used methods for obtaining pure cultures of microorganisms are streak-plate, pour-plate, and spreadplate. Serial dilution can also be used for a pure culture by serially diluting the sample with sterile water to the point of extinction in numbers of cells. The streak-plate method offers a most practical method of obtaining discrete colonies and pure cultures. In this method, a sterilized loop or transfer needle is dipped into a suitable diluted suspension of organisms which is then streaked on the surface of an already solidified agar plate to make a series of parallel, non-overlapping streaks.

Under sterile conditions with the using of streak plate technique bacteria that, according to the form, appearance, optical property, pigmentation and texture, similar to Streptococcus spp., Staphylococcus spp. and other bacteria that could potentially be pathogenic from oral cavity were inoculated to the Petri plates, and incubated at $36-37{ }^{\circ} \mathrm{C}$ for 48 hours.

Identification of bacteria. Several stains and staining procedures are available to study the properties of various microorganisms and their differentiation into specific groups/genera/species. The acidic dyes (e.g. picric acid, acid fuchsin, eosin), the basic dyes (e.g. methylene blue, crystal violet, safranin) are often used. Staining solutions are prepared by dissolving a particular stain in either distilled water or alcohol. The stain is applied to smears for $30-60$ seconds, washed, dried and examined under the microscope.

Cultures' smears were taken with the use of a staining loop, placed to the microscope slides, stained; bacteria of different species were identified under the microscope view. As the result two species of Yersinia - the sample from the tongue and toothbrush, Neisseria spp. - the sample from the front and back teeth were identified (Fig. 3). Bacteria of Streptococcus spp., Staphylococcus spp. - the sample from the teeth and cheeks of $\alpha$-hemolysis were identified (Fig. 4). 

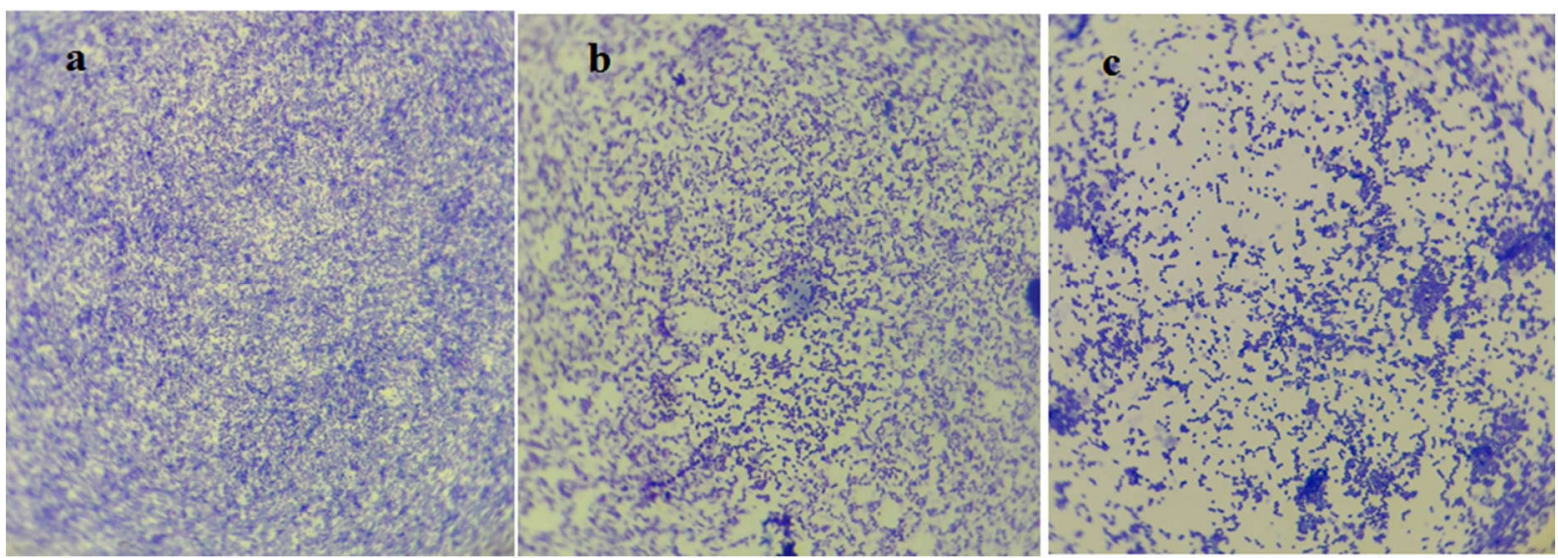

Fig. 3 The sample of Yersinia spp. from the tongue (a), from the toothbrush (b), the sample of Neisseria spp. from the front and back teeth (c) under microscope view (x800)
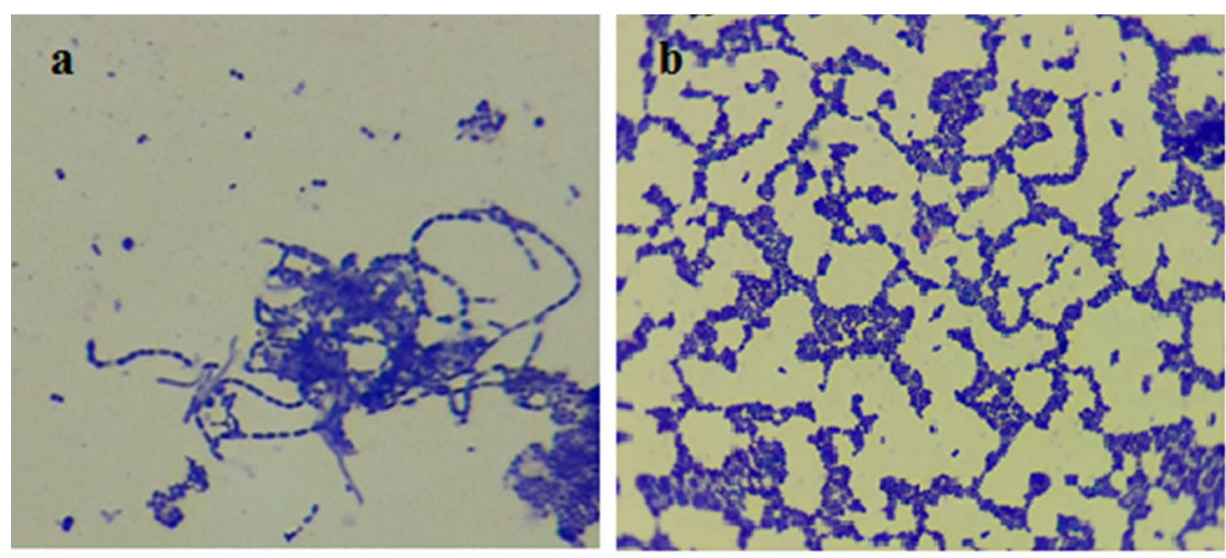

Fig. 4 The sample of Streptococcus spp. from the front and back teeth (a), the sample of Staphylococcus spp. from the cheeks (b) under microscope view (x800)

Preparation of medicinal plant extracts. Extraction is the crucial first step in the analysis of medicinal plants. On the table 1 the most crucial medicinal plants that are used against pathogenic microbial flora is listed. They were used for the determination of antagonistic activity against bacteria of oral and cavity. Water-extracts of medicinal plants were prepared as follows: $5 \mathrm{~g}$ of dry crushed raw material filled up $50 \mathrm{ml}$ of hot distilled water $\left(80^{\circ} \mathrm{C}\right)$, boiled for 1 hour in a water bath at a temperature of $60{ }^{\circ} \mathrm{C}$ and filtered. 
Table 1

Antagonistic activity of medicinal plants

\begin{tabular}{|c|c|c|}
\hline Medicinal plant & Action & Microorganisms \\
\hline $\begin{array}{l}\text { Eucalypti viminalis } \\
\text { folia }\end{array}$ & $\begin{array}{c}\text { antiviral, } \\
\text { bacteriostatic }\end{array}$ & $\begin{array}{l}\text { viruses; Proteus vulgaris, } \\
\alpha \text {-hemolytic streptococci }\end{array}$ \\
\hline $\begin{array}{c}\text { Calendula } \\
\text { officinalis flores }\end{array}$ & bactericidic & staphylococci, streptococci \\
\hline $\begin{array}{c}\text { Thymi serpylli } \\
\text { herba }\end{array}$ & $\begin{array}{l}\text { bacteriostatic, } \\
\text { bacteriocidic }\end{array}$ & $\begin{array}{l}\text { cocci, Gram-negative } \mathrm{m} / \mathrm{o} \\
\text { pathogenic fungi }\end{array}$ \\
\hline Chelidonii herba & bacteriostatic & $\begin{array}{l}\text { Gram-positive, } \\
\text { Gram-negative } \\
\text { Mycobacterium } \quad \text { tuberculosis; } \\
\text { fungi }\end{array}$ \\
\hline Salviae folia & bacteriostatic & $\begin{array}{l}\text { dysenteric bacteria, coliform } \\
\text { bacteria, Staphylococcus aureus, } \\
\alpha \text {-hemolytic streptococci }\end{array}$ \\
\hline $\begin{array}{c}\text { Artemisiae absinthii } \\
\text { herba }\end{array}$ & $\begin{array}{l}\text { bacteriostatic, } \\
\text { bacteriocidic }\end{array}$ & $\begin{array}{l}\text { Pseudomas aeruginosa, } \\
\text { Klebsiella } \\
\text { Staphylococcus aureus; } \\
\text { Shigella sonnei, Bacillus subtilis }\end{array}$ \\
\hline Matricariae flores & bacteriostatic & staphylococci, streptococci \\
\hline Urticae folium & bacteriostatic & $\alpha$-hemolytic streptococci \\
\hline
\end{tabular}

In diffusion technique, a reservoir containing the test compound at a known concentration is brought into contact with an inoculated medium and the diameter of the clear zone around the reservoir (inhibition zone in $\mathrm{mm}$ ) is measured at the end of the incubation period. In order to enhance the detection limit, the inoculated system is kept at lower temperature $\left(25-30{ }^{\circ} \mathrm{C}\right)$ for several hours before incubation to favour compound diffusion over microbial growth, thereby increasing the inhibition diameter. 
Different types of reservoirs can be used, such as filter paper discs (agar disc diffusion), holes punched in the agar medium (agar well diffusion) and stainless steel cylinders placed on the surface. The fixed agar is left on the bottom of the hole to ensure that the sample does not leak under the agar layer. The diffusion method is not appropriate for testing non-polar samples or samples that do not diffuse easily into the agar. In general, the relative antimicrobial potency of different samples may not always be compared mainly because of differences in physical properties such as solubility, volatility and diffusion characteristics in agar.

As the result transperent liquids of extracts of medicinal plants were obtained. Agar well diffusion method was used for the determination of antagonistic activity of extracts of medicinal plants on bacteria; synthetic mouthwash «Flour Aid 0.05» and organic mouthwash «Zubb» were used in order to demonstrate the effectiveness of extracts of medicinal plants against oral cavity's bacteria.

Analysis of the results of investigation. Table 2 presents a summary of the experiment agar well diffusion of extracts of medicinal plants on MRS against bacteria of oral cavity. Fig. 5 represents antagonistic activity of extracts of Eucalypti viminalis folia, Thymi serpylli herba, Chelidonii herba, Salviae folia, Artemisiae absinthii herba, Urticae folium as the most effective against bacteria of oral cavity. E. viminalis folia, T. serpylli herba demonstrate $60 \%$ of the effectiveness against the strain composition of Gram-positive and Gram-negative bacteria. U. folium, S. folia demonstrates $40 \%$ of the effectiveness against Gram-negative bacteria. C. herba, A. absinthii herba also demonstrate good antagonistic activity against certain strains of bacteria $(10 \%$ of the effectiveness) and are the perspective one for the further investigations. Extracts of C. officinalis flores, $M$. flores are not effective against investigated strains of bacteria. 
Table 2

Antagonistic activity of extracts of medicinal plants and mouthwashes on bacteria

\begin{tabular}{|c|c|c|c|c|c|c|c|c|c|c|}
\hline & \multicolumn{10}{|c|}{ Inhibition distance, $\mathrm{mm}$} \\
\hline & \multicolumn{8}{|c|}{ Extracts of medicinal plants } & \multicolumn{2}{|c|}{$\begin{array}{l}\text { Mouth- } \\
\text { washes }\end{array}$} \\
\hline & 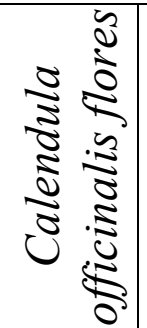 & 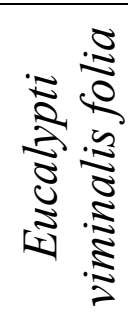 & 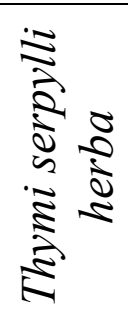 & 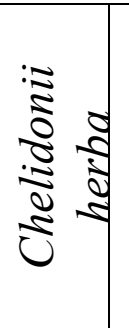 & 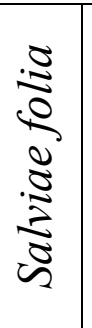 & 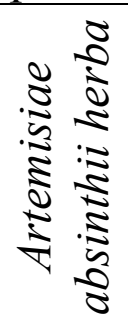 & 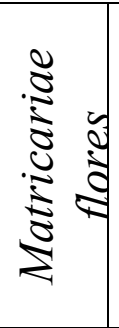 & 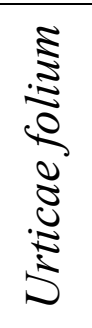 & 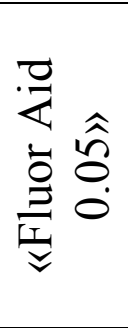 & 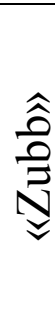 \\
\hline \multicolumn{11}{|c|}{ Oral cavity's bacteria } \\
\hline $\begin{array}{l}\text { Yersinia spp. } \\
\text { (tongue) }\end{array}$ & 0 & 2 & 3 & 0 & 2,5 & 0 & 0 & 1,5 & 4 & 4 \\
\hline $\begin{array}{l}\text { Yersinia spp. } \\
\text { (toothbrush) }\end{array}$ & 0 & 1,5 & 2 & 0 & 1,5 & 0 & 0 & 1 & 3 & 1 \\
\hline Neisseria spp. & 0 & 0 & 0 & 0 & 0 & 0 & 0 & 0 & 0 & 0 \\
\hline $\begin{array}{l}\text { Streptococcus } \\
\text { spp. (teeth) }\end{array}$ & 0 & 0 & 0 & 1,5 & 0 & 0 & 0 & 0 & 0 & 0 \\
\hline $\begin{array}{l}\text { Staphylococcus } \\
\text { spp. (1) }\end{array}$ & 0 & 4 & 1 & 0 & 0 & 1 & 0 & 0 & 0 & 0 \\
\hline
\end{tabular}

Inhibition distance, $\mathbf{m m}$

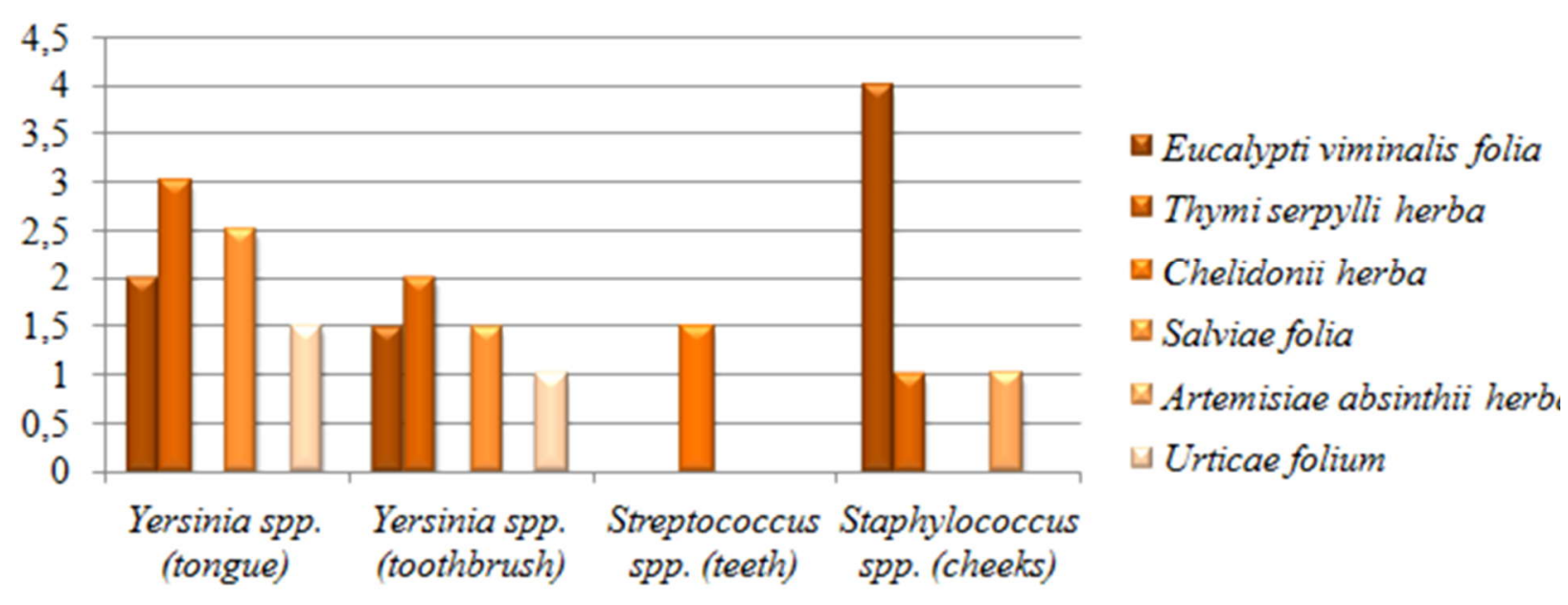

Fig. 5 Zone of inhibition of bacteria of oral cavity by medicinal plants' extracts 


\section{CONCLUSIONS}

1. The literature resources about problems associated with the use of synthetic drugs (the development of pathogenic microflora resistance, dysbiosis, frequent sideeffects and the emergence of allergic reactions), the perspectives of the use of herbal remedies instead of synthetic drugs (typically cause fewer side-effects comparing with the synthetic one) were analysed.

2. An appropriate method of extraction of biologically-active compounds from the herbs that could demonstrate antimicrobial activity was chosen.

3. Pure cultures of bacteria from oral and nasal cavity by growing pure colonies of microorganisms on Petri plates with the use of streak-plate technique, and enrichment, differential media were isolated and identified by morpho-phisiological characteristics.

4. Water-extracts of medicinal plants available on the territory of Ukraine were performed.

5. The features of antagonistic activity of extracts of medicinal plants on bacteria were analysed, as well as, the optimal medicinal plants with the high antibacterial activity were found.

\section{REFERENCES}

1. Рослини з протимікробними властивостями / Н. Є. Стадницька [та ін.]. // Вісник Національного університету «Львівська політехніка». - 2011. - № 700. C. $111-116$.

2. Benefit-risk appraisal of medicines: a systematic approach to decision-making / Mussen F., Salek S., Walker S.; with forew. S. A. Breckenridge. - West Sussex : John Wiley \& Sons, Ltd, 2009. - 293 p.

3. Microbiota dysbiosis: a new piece in the understanding of the carcinogenesis puzzle : Journal of Medical Microbiology [Electronic resource]. - 2016. - № 65. P. 1347-1362. - Access mode:http://jmm.microbiologyresearch.org/content/journal/ jmm/10.1099/jmm.0.000371;jsessionid=y4Itzmh8wryxTvrc8fF_TsD6.x-sgm-live-02 . - Title from the screen. 
4. Дудик I. П. Актуальність застосування фітопрепаратів як лікувальнопрофілактичних засобів у пародонтологічних хворих / I. П. Дудик // Клінічна стоматологія. - 2016. - № 2. - С. 8-13.

5. Alamgir A. N. M. Therapeutic use of medicinal plants and their extracts: volume 1: pharmacognosy / A. N. M. Alamgir. - Bangladesh : Springer International Publishing, 2017. - 545 p.

6. Extraction, isolation and characterization of bioactive compounds from plants' extracts : African journal of tradition, complementary and alternative medicines : AJTCAM [Electronic resource]. - 2011. - Vol. 8 (1). - P. 1-10. - Access mode: https://www.ncbi.nlm.nih.gov/pmc/articles/PMC3218439/. - Title from the screen.

7. The human microbiota in health and disease [Electronic resource]. - 2017. Vol. 3 (1) - P. 71-82. - Access mode: https://www.sciencedirect.com/science/article/ pii/S2095809917301492. - Title from the screen.

8. Traditional medicinal plant extracts and natural products with activity against oral bacteria: potential application in the prevention and treatment of oral diseases : Evid based complement alternat med. [Electronic resource]. - 2011. - Vol. 2011 - 15 p. - Access mode: https://www.hindawi.com/journals/ecam/2011/680354/. - Title from the screen.

9. Aneja K. R. Experiments in microbiology, plant pathology and biotechnology / Aneja K. R. - New Delhi : New Age International (P) Ltd., 2003. $609 \mathrm{p}$.

10. Клепач Г. М. Дослідження способів екстракції біологічно активних речовин із пижми звичайної (Tanacetum vulgare l.) / Г. М. Клепач, І. В. Карп’як. // Науковий часопис Національного педагогічного університету ім. М. П. Драгоманова. - 2013. - № 5. - С. 75-80. 


\title{
ВИЗНАЧЕННЯ АНТАГОНІСТИЧНОЇ АКТИВНОСТІ ЕКСТРАКТІВ ЛІКАРСЬКИХ РОСЛИН НА БАКТЕРІЇ РОТОВОЇ ПОРОЖНИНИ
}

\author{
Ю. В. БОРИСЕНКО, М. М. БАРАНОВСЬКИЙ \\ Національний авіаційний університет, Київ
}

Проблема останнього десятиліття тісно стосується використання синтетичних лікарських засобів. Натуральні продукти надають необмежені можливості для нових відкриттів лікарських препаратів. Організм людини та його мікробна флора становлять складну екосистему. Будь-які зрушення рівноваги можуть спричинити розвиток інфекиійних захворювань. Важливо вивчити особливості антагоністичних властивостей екстрактів лікарських рослин для розробки рослинних препаратів для лікування та профілактики інфекиійних захворювань, оскільки це є одним з актуальних завдань сучасної біотехнології.

Ключові слова: ротова порожнина, лікарська рослина, екстрагування, антагоністична активність, лунко-дифузійний метод, інгібування.

\section{ОПРЕДЕЛЕНИЕ АНТАГОНИСТИЧЕСКОЙ АКТИВНОСТИ ЭКСТРАКТОВ ЛЕКАРСТВЕННЫХ РАСТЕНИЙ НА БАКТЕРИИ ПОТОВОЙ ПОЛОСТИ}

\section{Ю. В. БОРИСЕНКО, М. М. БАРАНОВСКИЙ}

Национальный авиационный университет, Киев

Проблема последнего десятилетия тесно касается использования синтетических лекарственных средств. Натуральные продукты предоставляют неограниченные возможности для новых открытий лекарственных препаратов из-за наличия химического разнообразия. Организм человека и его микробная флора составляют сложную экосистему, равновесие которой служит прекрасным примером взаимной адаптации. Любые сдвиги 
равновесия могут привести к развитию инфекционных заболеваний. Важно изучить особенности антагонистических свойств экстрактов лекарственных растений для разработки растительных препаратов для лечения $u$ профилактики инфекционных заболеваний, поскольку это является одной из актуальных задач современной биотехнологии.

Ключевые слова: ротовая полость, лекарственное растение, экстрагирование, антагонистическая активность, лунко-диффузный метод, ингибирование. 